\title{
INTERIØRER PÅ FREDERIKSBORG
}

\author{
Mette Skougaard
}

Kongeslottet $i$ Hillerod, som blev bygget af Christian IV i begyndelsen af 1600-årene, blev efter en ødelaggende brand 1859 genskabt, og på brygger J.C. Jacobsens initiativ indrettet til nationalhistorisk museum 1878. Enhver gast på museet har umiddelbart kunnet glade sig over slottets pragtfulde og varierende interiører. I virkeligheden er der imidlertid tale om flere forskellige typer af interiører, der har vidt forskellig karakter og baggrund, som vil blive behandlet $i$ det folgende. Det drejer sig for det forste om de originale interiorer, der overlevede branden i 1859. Dernast er der de rum, som efter branden blev genskabt i en form, som skulle fore dem tilbage til Christian IVs tid, og endelig er der de egentlige museumsinteriører, som kunne ses på museet fra 1884. Artiklen påpeger en hidtil upåagtet, meget nar sammenhang mellem disse tidligste interiører og den store nordiske Kunst- og Industriudstilling i København 1879, og belyser de overvejelser, museets skabere gjorde sig vedrørende museets indhold og form.

\section{DE ORIGINALE INTERIØRER}

Da storbranden hærgede Frederiksborg Slot i december 1859 gik uvurderlige kulturværdier til grunde i de mange interiører med deres udstyr af malerier, gobeliner, møbler med videre, som var blevet samlet her gennem århundreder. Lykkeligvis blev nogle rum delvis sparet for brandens værste ødelæggelser. Det drejer sig om Kirken, Audienssalen og Løngangen. Løngangen og Audienssalen fik deres udformning i 1680erne, idet netop disse rum blev ødelagt ved en brand i 1665. De fremstår i baroktidens stil, skabt under stærk inspiration fra Italien og Frankrig. Audienssalen er således et storslået repræsentationsrum, der med hele sit dekorative udstyr forherliger enevældens ide, og rummet regnes i dag som hovedværket i barokkens interiørkunst i Danmark.

Kirkesalen har i store træk den originale udsmykning fra Christian IVs tid. Det overdådigt udsmykkede rum indeholder også en væsentlig del af det originale inventar med bl.a. altertavle og prædikestol fra guldsmedefamilien Mores i Hamborg og det berømte Compeniusorgel, som blev skænket til kirken af kongens søster i 1617. Kirkerummet og dets udstyr kan give os en ide om, hvor prægtigt Frederiksborg Slot blev udstyret af Christian 
72 IV, og hvor højt hans ambitionsniveau har været. Med beskrivelserne fra 1600-tallet ved hånden er det muligt at vandre gennem nogle af de øvrige rum og forestille sig, hvordan de så ud da slottet var nyindrettet og kongens foretrukne residens.

Det første den besøgende på slottet trådte ind i var Drabantstuen i Kongefløjens nederste stokværk, det der i dag er museets forhal. ${ }^{1}$ Fra denne enkelt indrettede vagtstue var der adgang til Ridderstuen, det største rum i hele fløjen, der tjente som kongens og hoffets spisesal

På gulvets grå og brune marmorfliser stod et større antal borde med bænke og stole. Antagelig var bordene efter tidens skik samlet til lange borde, som har været placeret i en Uform med højbordet midt for. Gæsterne har i givet fald siddet ved ydersiden af bordene med ryggen mod væggen, således at der har været åbent for servering fra indersiden. Stolene var udstyret med gyldenlæder og gule silkefrynser, bænkenes hynder af rødt blomstret fløjl med røde frynser. Maden skulle bringes fra køkkenet i sidefløjens kælder og tværs over gårdspladsen for derefter at blive anrettet i Drabantstuen. Om nødvendigt kunne retterne yderligere varmes op ved kaminen i Ridderstuen, hvor de bevægelige kogeringe til potter og pander stadig ses. Tallerkener, kander, drikkepokaler og andet nødvendigt udstyr har kunnet opbevares på tre skænke placeret langs væggene. Sammen med musikanterstolen og karmen rundt om indgangsdøren til Drabantstuen har de strålet af farver og forgyldninger.

Væggene var draget med sort spansk gyldenlæder og udsmykket med 19 råbukkehoveder i relief. Disse blev dog nedtaget i 1788, da Ridderstuen blev indrettet til ophængning af afdøde ridderes våbener. Belysningen ud- gjordes af 13 lysearme på væggene, disse var formet som en mandsfigur der holdt to lysepiber i hænderne. Midt i salen bar de fem søjler med polerede marmorskafter loftets krydshvælvinger, som var prydet med de kongelige våben i stukkaturen.

Utvivlsomt har der været mange glade og lystige stunder i denne sal, når de fulde pokaler har kredset rundt omkring de lange borde, mens trompeterne fra musikanterstolen lydeligt forkyndte de udbragte skåler. Salen var dog også rammen om nogle af de tunge begivenheder i kongens liv. Her udspilledes den pinagtige scene en januardag i 1630, hvor spændingerne mellem Kirsten Munk og kongen var på det højeste, hvor fru Kirsten sad "bister gal” og græd hele tiden, mens der blev holdt taffel, og da man gik fra bordet, kastede hun sig "af ondskab" som kongen skrev, på brændet ved ildstedet, så hun rullede ned på flisegulvet med brændebunken omkring sig. Næste dag skiltes hun og kongen for stedse (Beckett 1914: 130-31).

Næste etage, det andet stokværk, var forbeholdt kongen og dronningen og derfor på alle måder det anseligste, indrettet med højere til loftet og større vinduer end de øvrige stokværk og udstyret med karnapper i de store sale. Rummene var fordelt efter den typiske sidebetonede renæssanceplan, hvor de to store sale indtog henholdsvis det østlige og det vestlige gavlparti i hele bredden; imellem dem lå de øvrige gemakker, der dels var indbyrdes forbundne, dels kommunikerede med to smalle gange ud mod slotsgården.

Dronningens værelser lå i den østlige del, kongens mod vest. Alle gulvene var belagt med marmorfliser. De prægtigste rum var de to sale samt kongens og dronningens respektive smykkekamre eller påklædningsværelser. Her var der indsat trælofter med udskårne felter, der var 
malede og forgyldte. I kongens sal så man således heste anbragt i landskaber. Det siges udtrykkeligt, at portalerne i de to store sale var prydede med søjler. Vandret inddeltes værelserne efter renæssancens skik af lister anbragt i mandshøjde. Over dem var malerierne placeret, under dem de vævede tapeter i guld, sølv og silke, gyldenlæder eller opslået rødt klæde.

Dronningens rum bestod af Vintersalen, soveværelse, smykkekammer, det blå gemak og en gang. I Vintersalen stod tre store skabe, de såkaldte tresurer. To var af egetræ, malede og forgyldte med udskæringer, det tredje af ibenholt med indlægninger. Man hører, at der var opstillet kostbart nips på dem. På ibenholtskabet stod to store nautiler indfattet med sølv og prydet med store diamanter. På det ene af egetræsskabene stod sølvforgyldte pokaler, på det andet en udstoppet leopard med en marmorkugle under højre forpote. Væggene var draget med rødt klæde under listerne, og ovenover dem hang malerier og to flamske tapeter "med guld indvævet". Over bordet i stuen svævede en bordhimmel med rygstykke i fire bredder af guld- og sølvmor ${ }^{2}$ med frynser af hvid og gul silke. Bordet har været prydet med gul fløjlsdug, vævet med roser på en hvid bund. Den fornemmeste stol var udstyret med sølvmorsbetræk med sølvbund og blomster på vævet med guldtråd og mange forskellige farver silke. Hoffets damer kunne i ledige stunder hvile sig på hynder med guldmors betræk, foret med gul damask. Ved indgangsdøren til salen stod et springvand af udskåret og malet træ - måske har vandet været velduftende rosenvand. Rummet har været oplyst af en prægtig messinglysekrone med 16 piber (Beckett 1914:134).

Dronningens smykkekammer eller påklædningsværelse var ligeledes særdeles luksuriøst indrettet. På væggene hang foruden malerier prægtige tavler af alabast og guldmorstapeter og i vinduerne lå hynder betrukket med gyldenstykke. Blandt skattene herinde opbevaredes et sjældent og uhyre kostbart næsten 4 alen langt enhjørningehorn (som i øvrigt på et senere tidspunkt blev medbragt af Corfitz Ulfeldt på en diplomatisk mission og skænket til Ludvig XIV). Til det prægtige udstyr i smykkekammeret hørte også to ibenholtskabe med sølvbeslag og sølvindlægninger, hvor det ene indeholdt toiletsager. Et kostbart spejl i ramme af ibenholt med beslag af drevet sølv var anbragt over et bord med ibenholtplade, som blev benyttet som toiletbord. Pragtstykket i rummet var dog den sølvforgyldte lysekrone, som havde kostet kongen 450 daler. Den var udstyret med et urværk med to klokker som slog både time og kvarterslag (Beckett 1914: 133-34).

I dronningens sovekammer stod et bord dækket med persisk guldmor. Væggene var beklædt med spansk gyldenlæder og malerier. Sengen var lavet "på indiansk vis", det vil sige lakeret. Dens himmel, kapper og omhæng var af blåt guldmor broderet med guld og sølv og besat med gyldne possementer. Sengetæp var af blå atlask, broderet med store perler, gyldne roser og forskellige diamanter, foret med rød taft. Fjerdynerne var betrukket med dobbelt taft. Vinduerne var pyntet med røde guldmors flæsebesætninger, stolene beklædt med persisk guldmor eller med rødt silkebetræk (Beckett 1914:133).

Herfra førte en gang til kongens sovekammer. Christian den IVs seng beskrives som "et lidet felt sengested" med sorthvide stolper. Himlen af rød damask sad på en ramme af forgyldt træ, der bar en dobbelt kappe ligeledes af rød damask kantet med guldpossementer og frynser af guld og rød silke. Omhænget var i fem lange stykker rød damask, besat med 
74 guldpossementer. Sengetæppet var udført i samme materialer. Selve sengelejet bestod af tre grønne atlaskes underdyner, to grønne atlaskes hovedpuder, en brandgul atlaskes overdyne, en blå taftpude og en blå underdyne (Petersen 1866:31-32).

Både dronningens og Christian IVs seng var af den type, der i 1600-årene vandt indpas i stedet for de udskårne, tunge stolpesenge, som dominerede i 1500-årene. De nye såkaldte tapetseri-senge var meget lettere, idet det faste træloft blev erstattet med en himmel af stof, spændt på rammer med en omløbende kappe. Omhænget skulle være glat og slutte tæt om sengen, således at det kunne lukkes helt tæt om aftenen, mens det om dagen kunne opfæstes eller trækkes til side. Sovekammerets vægge var omdraget med rødt engelsk klæde og i øvrigt kun møbleret med en enkelt silkebetrukket stol og et par borde.

Blandt kongens rum var Sommersalen naturligt nok det prægtigste med ikke mindre end tre pragtspejle, det ene placeret over kaminen med en ramme af sort marmor med søjler hvis skafter var af alabast med forgyldte kapitæler. De to andre var af ibenholt, prydet med sølvlister og figurer af sølv. Rammen om det ene af disse kunne åbnes og der kom da ni sølvbeslagne skuffer til syne. Her gemte kongen sit sølvskrivetøj. Forneden under rammen var der desuden et fint urværk af sølv.

Vinduerne i salen var udstyret med forhængsgardiner af taft holdt sammen med hvid silkesnor. På flisegulvet lå et stort tyrkisk tæppe som også af og til brugtes i Ridderstuen, hvor det lagdes under kongens bord, når der blev holdt taffel. Pragtstykket i rummet, en af slottets seværdigheder, var den vandkunst, som var opstillet i karnappen. På en fod af ibenholt bar en muslingeformet sølvkumme fire sølvforgyldte figurer, hvorfra vandet sprang ned i kummen og videre ned i en anden kumme, hvor der svømmede små fisk. Salen blev oplyst af en messinglysekrone med 15 lysepiber. Gæsterne kunne sidde på stole og bænke, udstyret med puder og hynder i silke og fløjl. Der var desuden en del simple malede fyrretræsborde, som blev dækket af tunge, kostbare guldmors- og fløjlstæpper. Langs væggene stod tre pragtskabe, det ene af ibenholt med beslag og indlægning af sølv, de to andre af sort og brunt "indiansk" træ. Det ene af disse skabe var med glasdøre og omtales som et apotek, det vil sige medicinskab. På væggene hang 15 vævede tapeter med forskellige motiver, bl.a. et som viste kongens hund Tyrk (Petersen 1868:23-28).

Det tredje stokværk havde samme grunddisposition som det andet stokværk, med to store sale mod henholdsvis øst og vest. Den store sal mod øst blev kaldt Skibssalen på grund af de udskårne, malede og forgyldte skibe, hvaler og fisk, der prydede loftet. Det var en af de pragtfuldeste sale på slottet med tapeter vævet med guld, sølv og silke, hvis motiver var lutter søstykker. Den vestlige sal omtaltes som "fru Mutters gemak" eller "gammel dronningens taffelstue", et levn fra 1613, hvor kongens moder enkedronning Sophie gæstede slottet. Det tredje navn, "Englesalen", hentydede til de udskårne og bemalede englefigurer, som prydede loftet. Foruden Englesalen og det tilstødende værelse i runddelen bestod enkedronningens lejlighed af et soveværelse ud mod søen og et opholdsværelse, "gammel dronningens liden stue", ind mod slotsgården. I øvrigt var stokværket oprindelig særlig forbeholdt kongens nære kvindelige pårørende, og det store antal senge i kamrene viser deres funktion som gæsteværelser.

Sengen i runddelen var nok den prægtigste på slottet overhovedet, købt i 1621 hos den 


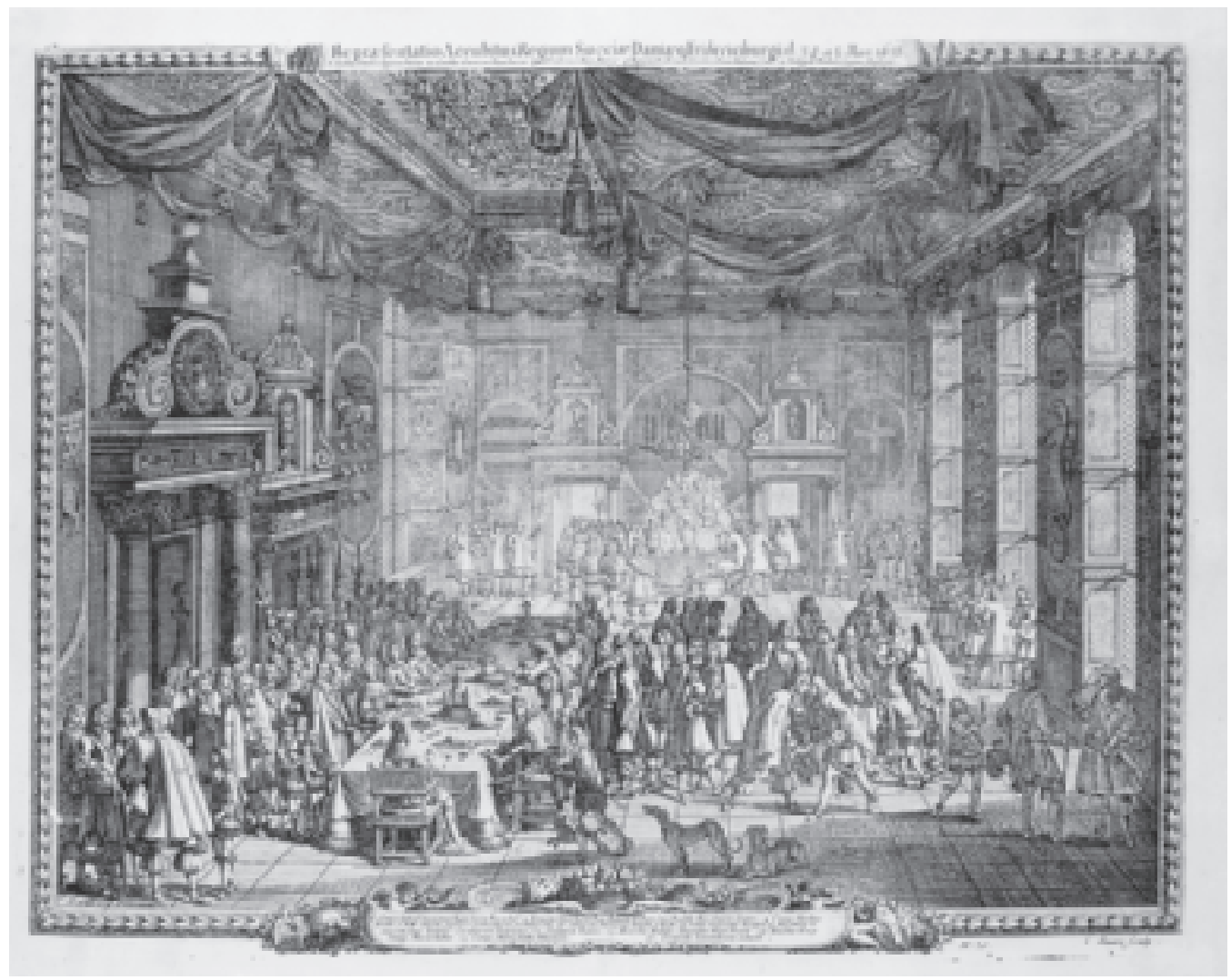

Den svenske konge Karl Gustav som det danske kongepars gast på Frederiksborg efter fredsslutningen i Roskilde 1658. Det eneste kendte interiørbillede fra slottet i 1600-tallet, som giver et indtryk af rummenes pragtfulde udsmykning. Kobberstik af I. Pautre efter tegninger af Erik Dablbergh.

hamborgske guldsmedefamilie Mores for 8000 speciedaler. Det var den såkaldte sølvseng, hvis fødder og piller var af ibenholt med sølvornamenter, og hvis sengestolper udgjordes af figurer i støbt og ciseleret sølv. Omhænget og himmelen var af sort, glat fløjl, overalt broderet med sølv og med C4s kronede navnetræk broderet med guldtråd på blå atlask, hvor kronerne var besat med perler og små granater. Kappen og sengetæppet var ligeledes af sort glat fløjl med kongens våben broderet med guld- og sølvtråd og adskillige farver silke. Væggene var under de mandshøje lister betrukket med sort caffa, (et østerlandsk fløjlsstof) med brandgule blomster kantet med possementer af guld og silke. Over listerne dækkedes væggene helt af billeder. Iblandt dem sås det kendte maleri der fremstillede kongens syn på Rothenborg den 8. december 1625. Af møbler fandtes desuden et sølvbord med tæp- 
76 pe "broderet med skønne figurer", som det hedder i beskrivelsen, hvorover hang en himmel af rød guldmor med sølvblomster, sammensyet i skiftende striber af stoffernes bredde. Stolene var betrukket med rødt fløjl eller spansk gyldenlæder.

Det pompøse sorte fløjl med de danske våben broderet i guld og sølv dannede også bunden i vægtapeterne i den tilstødende Englesal, hvor himlen over bordet med tilhørende rygstykke og bordtæpper var udført i tilsvarende materialer. Herinde var ikke mindre end 17 stole, kostbart betrukket med hynder af silke, fløjl, guldmor og damask. Tre af dem var desuden besat med perler (Petersen 1868:4045).

Denne kortfattede gennemgang af udvalgte rum illustrerer med al ønskelig tydelighed den overflod man mødte på Christian IVs Frederiksborg. Møbler og andet inventar i de kostbareste materialer, gobeliner vævet med silke, sølv og guldtråd, tekstiler til overflod således at man nærmest har vadet rundt i guld- og sølvmor, silke, atlask og fløjl, prydet med broderier, perler og ædelsten. Kongen vidste nok, hvad han gjorde, og hvorledes hans hof skulle leve op til normerne for datidens europæiske hofkultur, hvor forherligelsen af fyrsten i form af stor pragtudfoldelse, bl.a. i boligindretningen, var et led $\mathrm{i}$ kongemagtens forsøg på at styrke sin prestige og magt i forhold til andre fyrster og internt i forhold til rigets adel.

Under de følgende konger blev der naturligvis foretaget mange forskellige ændringer af slottets interiører i takt med skiftende behov og boligidealer. På Christian Vs tid blev eksempelvis runddelen ved Sommersalen bragt $\mathrm{i}$ stand og udstyret med hvide atlaskestapeter med indvævede røde blomster og kongens kronede navnetræk i guldtråd, foroven kantet med røde og hvide silkefrynser. De seks marmore- rede stole i rummet blev betrukket med samme stof og kantet med samme frynser. For vinduerne var der atlaskesgardiner og blandt møblerne et lakeret skrivechatol.

Under Christian VI blev der foretaget større ændringer, nu indrettedes mindre værelser og flere ildsteder. Det store hofapparat med mange hoffolk og tjenestefolk krævede flere værelser på slottet, og de mindre rum har været en stor behagelighed sammenlignet med de store, kolde og klamme sale, der aldrig kunne blive helt opvarmede. Stengulvene var meget fodkolde, hvorfor der blev indlagt trægulve i de fleste af slottets rum samt lettere fløjdøre, nye vinduer og nye stuklofter (Beckett 1914). Alt gik dog tabt med branden i 1859 .

\section{De GENSKABTE INTERIØRER}

Efter branden gik man meget hurtigt i gang med at genskabe kirken, som kunne genindvies den 28. august 1864. Restaureringen var en selvfølgelig ting, da den som sognekirke var et brugsrum. Men det blev også relativt hurtigt besluttet at genskabe Kongens Bedekammer, der stod som et gabende tomt hul under orgelkassen. Ikke fordi det skulle bruges til noget, men fordi det var et klenodie. Arbejdet med Bedekammeret kom i gang takket være brygger J.C. Jacobsen, der allerførst tog initiativ til udskrivning af en prisopgave om en tegnet fremstilling af rummet $i$ dets oprindelige skikkelse. Hermed skulle der leveres bevis for, at en rekonstruktion var mulig. Arkitekturmaleren Heinrich Hansen, der havde udført studier i Bedekammeret inden branden, var en selvskreven vinder af konkurrencen. Næste skridt var, at Jacobsen bestilte 23 religiøse malerier med motiver fra Det nye Testamente hos Carl Bloch. De skulle males på kobber som de nederlandske malerier, der oprindelig hav- 
de været indfældet i væggene og i nøjagtig samme format. Hermed var vejen beredt, og det Kunstflidslotteri, der 1860 blev stiftet for at skaffe penge til Frederiksborgs genindretning, påtog sig at dække omkostningerne (Andrup 1928:8, Bligaard 1987:27).

Bedekammeret repræsenterede det håndværksmæssigt ypperste, som overhovedet blev skabt under slottets genopbygning, hvad der blandt andet medførte at døren til Bedekammeret, udført efter Heinrich Hansens tegning, blev vist på Verdensudstillignen i Paris 1878, hvor den hjembragte en guldmedalje. Da Bedekammeret stod færdigt 1871, må det have fremstået som det allerhelligste i det ellers tomme slot (Bligaard 1987:27).

Det næste store arbejde med interiører, som blev sat i gang på Frederiksborg, var i en helt anden målestok end Bedekammeret, - nemlig intet mindre end Riddersalen. Tanken om at indrette det store rum må have forekommet nærmest hasarderet, men brygger J.C. Jacobsen og arkitekten bag genskabelsen af Frederiksborg, Ferdinand Meldahl, veg ikke tilbage for nogen udfordring. Målet var ikke at genopbygge og indrette salen i den stand, den havde umiddelbart før branden, den skulle føres tilbage til det udseende, den havde haft før svenskernes plyndringer i 1659. I løbet af 6 år, 1874-1880, var salen genskabt i sin grundform med marmorgulv og træloft. I rummets ene kortside genopstod den store marmorkamin med sølvudsmykning, der i den anden ende af salen blev modsvaret af en dominerende søjleportal omkring den nye indgang. Denne portal var en af Meldahl tegnet fri komposition i poleret træ med forsølvet figurskulptur og ornamenter. Senere kom trompeterstolen midt for den ene langvæg, nu ikke af ibenholt med sølv som den oprindelige, men af sortbejset lindetræ med forsølvede relieffer.
Forlægget for genskabelsen af Riddersalen fandt man i de malerier og tegninger, kunstnerne Heinrich Hansen og F.C. Lund havde udført kort tid før branden i 1859 (Bligaard 1987:28-29).

Arbejdet med udstyrelsen af Riddersalen var så omfattende, at det fortsatte mange år frem. Mest tidskrævende var udskiftningen af de malede, imiterede gobeliner, som siden begyndelsen af 1880erne havde dækket væggene. De blev efterhånden erstattet med ægte tapeter, udført af et til dette formål oprettet gobelinvæveri. Dette arbejde afsluttedes først i 1928. Det var ikke muligt at rekonstruere samtlige 26 tapeter, som Christian IV fik udført hos Karel van Mander i Delft med motiver fra Kalmarkrigen og kongens kroning foruden nogle genrebilleder. Heinrich Hansen og F.C. Lund havde dog lavet forskellige skitser og tegninger af nogle af dem, og på dette grundlag kunne kunstneren C.N. Overgaard udføre kartonerne som Frederiksborgmuseets væveværksteder under ledelse af Louise Dahlerup, Kristiane Konstantin-Hansen, Johanne Bindesbøll og Betty Månsson herefter omsatte i gobelin.

Man må være både imponeret og taknemmelig over, at det lykkedes i store træk at skabe et rum, som på trods af de umiskendelige 1800-tals stiltræk, alligevel giver et indtryk af slottets prægtigste sal på Christian IVs tid. Den besøgende behøver ikke megen fantasi for at forestille sig, hvorledes lysene fra de tre kæmpemæssige lysekroner på festaftener har skinnet i det blanke messing, strålet ud over loftets forgyldninger og stærke farver, hen over gulvets hvide og sorte, grønne og røde marmorfliser for at blive kastet tilbage fra gyldenlæder og sølv, ibenholt og blankt poleret marmor og oplyse de dunkle tapeter på salens vægge (Beckett 1914:166; Bligaard 1987:108-9). 


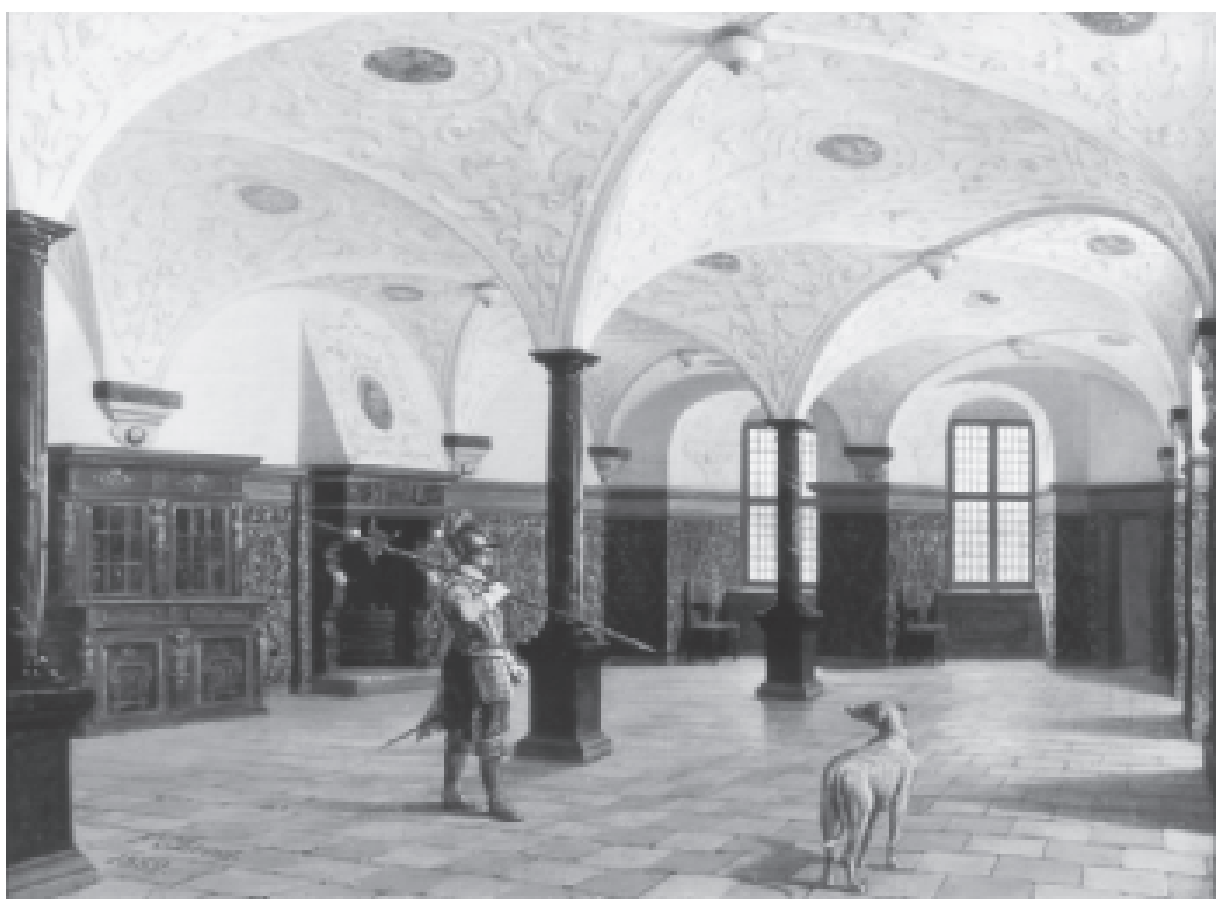

Ridderstuen (også kaldet Rosen). Studie udfort inden branden 1859 af F.C. Lund. Sammen med Heinrich Hansen udforte Lund en rakke studier af slottets interiører, der blev benyttet som grundlag for rekonstruktioner efter branden. Frederiksborgmuseet fot.

I 1876 tog brygger Jacobsen endelig initiativ til genskabelsen af endnu et rum på slottet. Det var Ridderstuen (også kaldet Rosen), som indtil branden havde bevaret en stor del af sin oprindelige indretning fra Christian IVs tid. Jacobsen tilbød at betale hvælvingernes restaurering og stukkatur, samt flisegulv og kamin. Takket være Heinrich Hansens og F.C. Lunds tegninger, udført umiddelbart før branden, samt bevarede rester af stukdekorationen kunne det lade sig gøre at foretage denne genskabelse. Hjortefrisen på væggenes øverste del var, som tidligere nævnt, fjernet tilbage i 1700 årene, og måtte skabes efter forbillede fra jagt- og dyrefriser på tyske renæssanceslotte, bl.a. Gottorp (Bligaard 1987:29-30).

\section{Museets Interiører}

Selvom Kirken, Riddersalen, Ridderstuen og Bedekammeret efterhånden blev genskabt, stod man stadig med utroligt mange nøgne rum, og en endelig beslutning om slottets fremtid var ikke truffet. Den 19. april 1877 rettede brygger J.C. Jacobsen på denne baggrund for første gang henvendelse til komiteen for genopførelse af Frederiksborg Slot og udkastede tanken om et nationalhistorisk mu- 
seum i slottets lokaler, som han også tilbød at møblere som et kongeligt residensslot, hvilket selvfølgelig måtte ske "i Christian IVs stil"3 (Schepelern 1964:1).

Komiteen anbefalede enstemmigt tilbuddet overfor ministeriet, og den 25. juni samme år bifaldt kong Christian IX, at komiteen modtog de af brygger Jacobsen tilbudte 200.000 kr. til den indre istandsættelse af Kongefløjen, imod at denne fløj fremtidigt anvendtes dels til festlokale ved større højtideligheder i kongehuset, dels til anbringelse af et nationalhistorisk museum, og museet blev en realitet fra april 1878 .

Når det drejer sig om, hvorledes slottets rum skulle udstyres, formulerede Jacobsen en slags program i sin skrivelse til Carlsbergfondets direktion i januar 1878. Han udtalte her, at der skulle tilvejebringes gamle mindesmærker i originaler eller kopier samt sådanne møbler, husgeråd, våben, rustninger osv. fra fortiden indtil Christian IVs og Frederik IIIs tidsalder, "som særlig egne sig til opstilling i denne gamle borg, hvis præg som sådan ikke derved bør forstyrres" (Schepelern 1964:2).

I det endelige kongelige reskript af 5. april 1878, hvor Frederiksborgmuseet oprettes, tales der kun om et nationalhistorisk museum i Kongefløjen, uden nærmere angivelse af formål og udstyr. Dette specificeredes først nærmere i statutterne af 7 . oktober 1878 . Hovedlinierne blev, at museet skulle udgøre såvel et oplysende supplement til som en fremtidig fortsættelse af de danske kongers kronologiske samling på Rosenborg og af de i øvrigt bestående kulturhistoriske museer. Der tales om "større, kunstnerisk udsmykkede lokaler" og med hensyn til museets indhold tales der foruden om portrætter - om "møbler, dragter, rustninger, våben og lignende, både for de forskellige tiders stil og for berømte person- ligheder betegnende genstande”. Mens man i begyndelsen kun tog sigte på et museum i Kongefløjen omfattende tidsrummet fra kristendommens indførelse til ca. 1660, skete der ved et tillæg 7. oktober 1878 en udvidelse, idet museets lokaler nu også skulle omfatte Prinsessefløjen og arbejdsområdet udvidedes til "vækkende og mere omfattende fremstillinger af fædrelandshistoriske minder fra kristendommens indførelse i Danmark til nyeste tid" (Schepelern 1964:2-3). Det vil sige, at der fra Jacobsens første udspil i foråret 1877 til de endelige statutter i oktober 1878 var sket en løbende præcisering af, hvorledes museet skulle udstyres, og at der skete en tidsmæssig udvidelse af dets emneområde. For at forklare denne udvikling er det nærliggende at se på det arbejde, der i samme periode foregik med hensyn til planlægning af idegrundlag og indhold i den store Kunst- og Industriudstilling, som skulle afholdes i København 1879. At der skulle være en forbindelse til Frederiksborg, kan ikke undre, når man erfarer, at udstillingskomiteens formand var arkæologen J.J.A. Worsaae, der indtog en central plads i dansk museumsvæsen, var direktør for Oldnordisk Museum og for De danske kongers kronologiske Samling på Rosenborg, medlem af Komiteen for Frederiksborg Slots Genopførelse og formand for Frederiksborgmuseets bestyrelse (Andrup 1928: 10-14). Udstillingskomiteen begyndte sit arbejde i oktober 1878, altså må Worsaae have siddet med formulering af kunstog industriudstillingens målsætning i samme tidsrum, som han arbejdede med definitionen af Frederiksborgmuseets statutter.

I en samtidig artikel beskrives Kunst- og Industriudstillingens ide således:

At søge svaret på hvorledes den store gåde som vi kalde livet, tog sig ud for de tidligere perioders mennesker, 


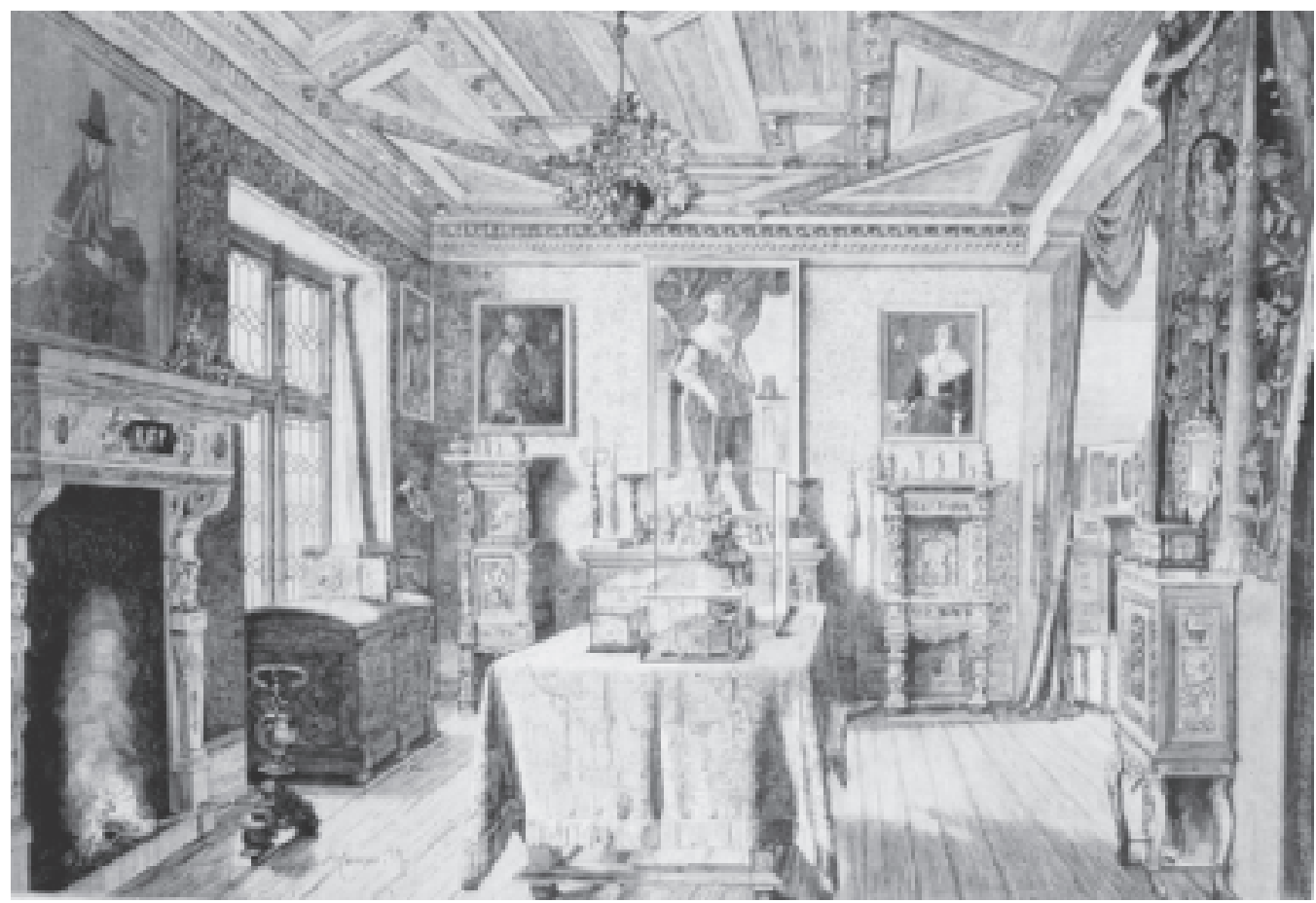

Fra Kunst- og Industriudstillingen i København 1879. Illustrationen viser et rum der til forveksling ligner de interiorer, man fra 1884 kunne se på Frederiksborg - endog med mange af de samme genstande og malerier. Illustreret Tidende $1879 \mathrm{nr} .1036$ s. 460, tegnet af I.T. Hansen. Frederiksborgmuseet fot.

hører med rette til de opgaver, som vor tids historieskrivning stiller i første række... Et betydeligt bidrag hertil give de retrospektive udstillinger, navnlig når de som tilfældet er med den udstilling, der for tiden afholdes hos os i Industribygningen, søge at samle hvad de forskellige perioder have frembragt i særegne rum, der hver for sig giver billedet af et vist bestemt tidsafsnit. Den historiske portrætsamling der ligesom en rød tråd snor sig gennem hele udstillingen, støttende og forklarende det billede af svundne tiders liv og virken som denne tilsigter at give er ikke den mindst interessante afdeling... (Illustreret Tidende 1879:457-58).
Det er ikke vanskeligt i denne beskrivelse at se lighedspunkterne til Frederiksborgmuseets udstillinger, der kunne ses på slottet fra 1884 , for også selve måden at udstille på må have været inspireret af Kunst- og Industriudstillingen. Man kan således konstatere en slående lighed mellem de indrettede stuer på slottet og industriudstillingens præsentationer i tidstypiske pragtinteriører med smukt møblerede rum udstyret med portrætter af centrale personligheder fra tiden. I mange tilfælde er der også ligefrem tale om de samme møbler og 


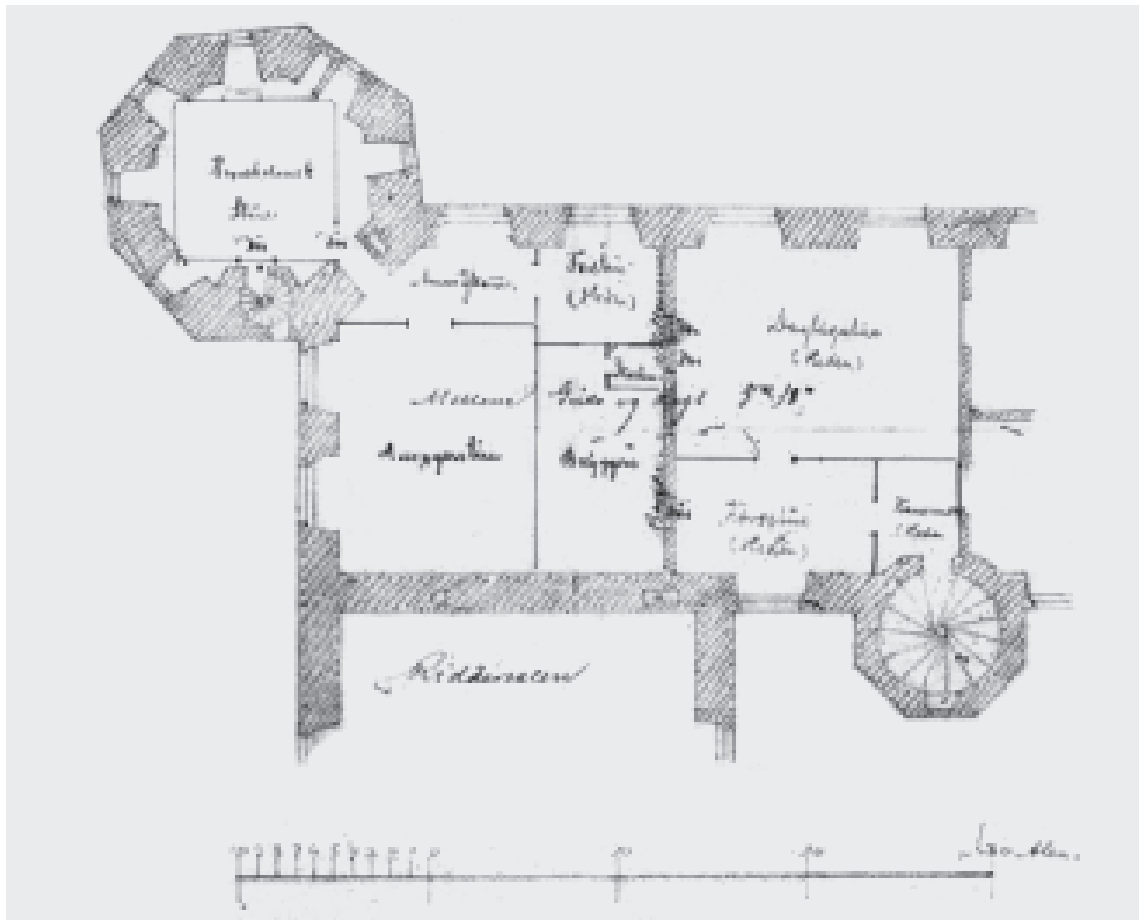

Bernhard Olsens tegnede plan over placering af bondestuer på Frederiksborg. Det drejer sig om stuer fra henholdsvis Hedeboegnen, Amager og Bornholm. Frederiksborgmuseets arkiv.

Frederiksborgmuseet fot.

genstande, hvilket hænger sammen med, at brygger Jacobsen, der var en flittig gæst på udstillingen, bevilgede et ekstraordinært tilskud og et rentefrit lån fra Carlsbergfondet til erhvervelse af udstillingens bedste ting, bl.a. en betydelig samling monumentale renæssancemøbler (Andrup 1928:16).

Der var mange gode grunde til at vælge netop denne udstillingsform, som i sit væsen harmonerer så godt med museets formål: At skabe et hjemsted for vækkende og mere omfattende fremstillinger af fædrelandshistoriske minder, hvor mødet med fortiden skulle udvikle den nationale bevidsthed hos beskueren. For at opnå en sådan vækkende fremstilling af nationens historie og derved nå ud til en bredere offentlighed med de nationale budskaber, har det spillet en stor rolle, ikke alene, hvilke genstande man indsamlede, men også hvordan de blev præsenteret. Hvis man ville have en bred gruppe af befolkningen i tale, måtte man tilpasse udstillingerne, så de appellerede til såvel de veluddannede som til lægfolk, og for at opnå dette var man nødt til at 
82 skabe en formel for den nationale kultur, som umiddelbart kunne fortolkes og forstås af et bredt udsnit af befolkningen.Ved indretningen af museets stuer blev alt da også gjort for at den besøgende i så høj grad som muligt skulle kunne indleve sig $\mathrm{i}$ fortiden og på den måde identificere sig med den nationale historie. Ved at overtage tidens mest moderne billedsprog og ved brug af naturalistiske og teatralske udtryk lånt fra tidens uhyre populære store udstillinger, blev præsentationen meget mere intens end ved den tids gængse præsentation af museumsgenstande, som typisk var arrangeret efter videnskabelige principper og præsenteret som systematisk arrangerede samlinger. Og det var netop det bemærkelsesværdige ved Industriudstillingens præsentationer.

Industriudstillingens interiører huskes i øvrigt i dag mest for de bondestuer, det lykkedes udstillingens særligt tilknyttede, Bernhard Olsen, at få indsamlet på meget kort tid. Han havde det særlige hverv at indsamle dragter, tekstil, bylavssager, møbler og hele stuer med tilknytning til bondestanden, og genstandene blev præsenteret i hele bondestuer med alt tilbehør opbygget som egentlige rum med loft og vægge. Disse stuer havde han fået inspirationen til efter at have set den svenske Artur Hazelius' præsentationer på Verdensudstillingen i Paris 1878, hvor bondestuerne tiltrak sig international opmærksomhed. Det samme gjaldt den hollandske afdeling, hvor man havde indrettet en stue fra Hindeloopen i Friesland, som gjorde et uforglemmeligt indtryk på Bernhard Olsen, for dette var en stue man kunne gå helt ind i og ikke bare beskue udefra. Bernhard Olsen skrev begejstret til Worsaae: "Denne måde at udstille på koster måske en ubetydelighed mere end når man stiller tingene op i montrer, men den giver en vidunderlig gribende virkning og vil jo selvfølgelig øve en overordentlig tiltrækning på publikum" (Rasmussen 1979:17-18).

Ved udstillingens ophør stod Bernhard Olsen med en større samling bondestuer og genstande og ønsket om at skabe et historisk-etnografisk museum eller et bondestandens museum. Arkitekt Ferdinand Meldahl havde givet en meget positiv bedømmelse af Olsens indsats og foreslog at løse hans problem ved at få denne bondestandssamling anbragt på Frederiksborg. Bernhard Olsen svarede naturligt nok meget positivt på Meldahls forslag. Det var magtpåliggende for ham at alt det der med så stort besvær var indsamlet ikke skulle forsvinde men blive kernen i et museum, og han kunne godt tænke sig muligheden for at blive tilknyttet Frederiksborg. Meldahl forelagde brygger Jacobsen disse tanker, og fik omgående positivt svar:

Jeg er ganske enig med Dem i at man bør søge at benytte Bernhard Olsens særlige dygtighed i den omhandlede retning, og at det vil være særdeles ønskeligt at få lignende typer på bondestuer fra andre dele af landet som de vi nu se på udstillingen. Det forekommer mig også at slige typer havde deres naturlige plads i et nationalhistorisk museum som Frederiksborg, hvor den øverste etage også synes at egne sig dertil.

Hans eneste betænkelighed var brandfaren, som en sådan samling af brændbare og til dels let fængelige sager ville medføre men det kunne klares ved en forsvarlig isolering af de anvendte rum (Rasmussen 1979:96).

Alt tegnede således godt, og planen var nu så fremskreden, at Bernhard Olsen havde indtegnet en række bondestuer på en plan af slottet, placeret umiddelbart ved siden af riddersalen. Meldahl havde dog overset en meget vigtig faktor - han havde glemt at underrette bestyrelsens formand, J.J.A. Worsaae, og denne deltog ikke i den almindelige begejstring 


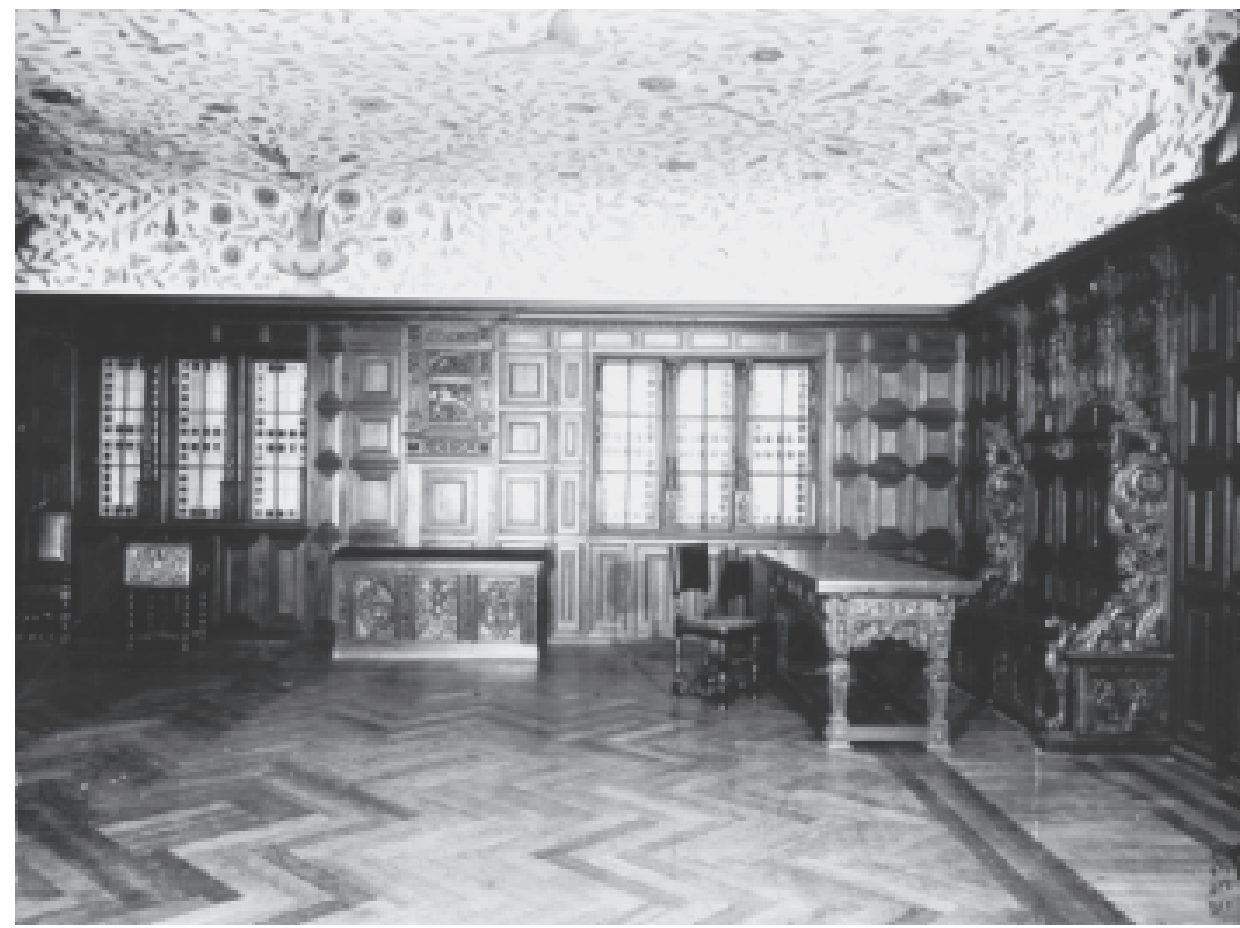

Ditmarskerstuen som på arkitekt Ferdinand Meldahls foranledning blev erhvervet til Frederiksborgmuseet fra en københavnsk antikvitetshandler i 1885, men atter blev nedtaget fä år efter Meldabls død $i 1908$. Frederiksborgmuseet fot.

over ideen. Han erklærede utvetydigt, at bondestuer umuligt ville kunne passe ind i et "dansk Versailles, et museum for vore store minder og store mænd". Og så påpegede han, at erhvervelsen stred mod museets statutter, der udtrykkeligt bestemte, at museet ikke skulle konkurrere med de kulturhistoriske museer, "hvor gamle bondestuer alene hører hjemme". Yderligere skrev han: "Selv om Capt. Jacobsen med sædvanlig velvilje var villig til at yde et extraordinart tilskud, vilde det i mine tanker være synd både imod ham og imod det af ham stiftede Nationalmuseum hvis man gik ind på at bringe de lave og i kunstnerisk henseende rå bondestuer i nogen som helst forbindelse med de øvrige kunstnerisk udsmykkede lokaler i Kongefløjen. Lad os for Guds skyld ikke gøre Frederiksborg til et broget pulterkammer og skabe det flere modstandere end det allerede har"(Rasmussen 1979:98-99).

Bondestuerne mente Worsaae til gengæld passende kunne indgå i et nyt Nationalmuseum som en ordentlig repræsentation af bondestandens vilkår i de nærmest forløbne århundreder, hvad der da også blev en realitet med Dansk Folkemuseum, oprettet 1885, og Frilandsmuseet, 1897, som blev en del af $\mathrm{Na-}$ tionalmuseet i $1920 .^{4}$ 


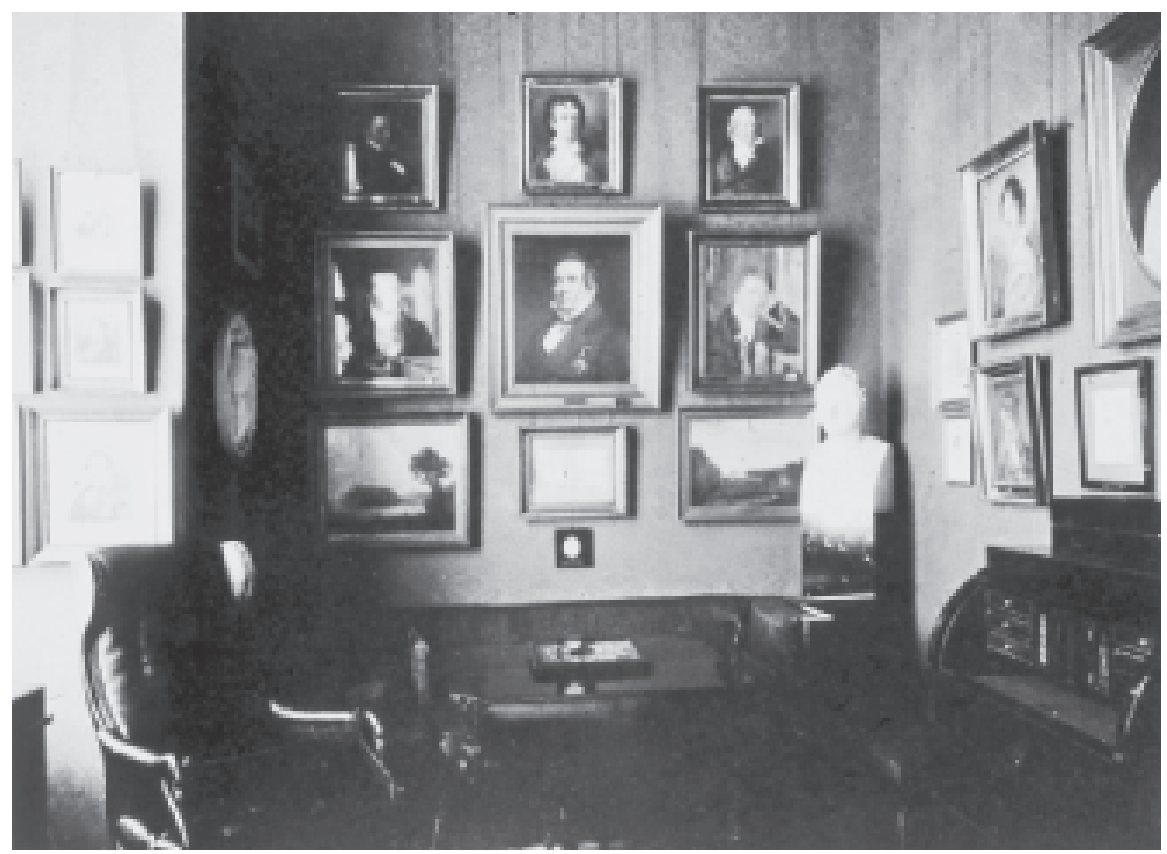

Mindestuen over Adam Oeblenschläger fotograferet i begyndelsen af 1900 ärene, hvor stuen var nyindrettet på museet. Ratsach fot. 1906

Meldahl lod sig dog ikke uden videre slå ud af kurs, og straks efter Worsaaes død i 1885 tog han atter fat på de gamle planer. Muligheden åbnede sig, da en københavnsk antikvitetshandler havde erhvervet en bondestue $\mathrm{i}$ Ditmarsken eller Holsten. Det var egentlig resterne af en panelleret og udskåret stue, som blev kompletteret og forbedret i København. Stuen blev udstillet og vakte en del opsigt. Meldahl så den og besluttede øjeblikkeligt, at den måtte erhverves til Frederiksborg. Museet fik den formedelst $20.000 \mathrm{kr}$., og den blev anbragt i et rum på slottets 3. sal. Bestyrelsen godkendte også, at stuen blev tilpasset rummet, der blev lagt nyt gulv, malet loft osv. Den i forvejen tvivlsomme vægbeklædning fik ikke noget mere troværdigt præg ved at blive udvi- det med den dobbelte vægflade eller ved at få helt nye vinduer, så som autentisk rumindretning var stuen ikke vellykket, og den blev ikke bedre af, at man lod en medaillon af Ole Worm skære til indsætning $i$ et felt over en af dørene. Måske kan det umiddelbart undre, at man overhovedet tænkte på at "invitere" bondestanden indenfor på det nationalhistoriske museum. Men i virkeligheden hænger det helt naturligt sammen med tidens opfattelse af det nationale, hvor netop folkekulturen og samlinger, som kunne belyse denne, blev opfattet som eksponenter for den virkelige, oprindelige og ægte nationale kultur, i smuk forlængelse af ideerne om den enkelte nationalstats kulturelle helhed som baserede sig på fælles sprog, historie og kulturelle særpræg. Stuen nåede dog 


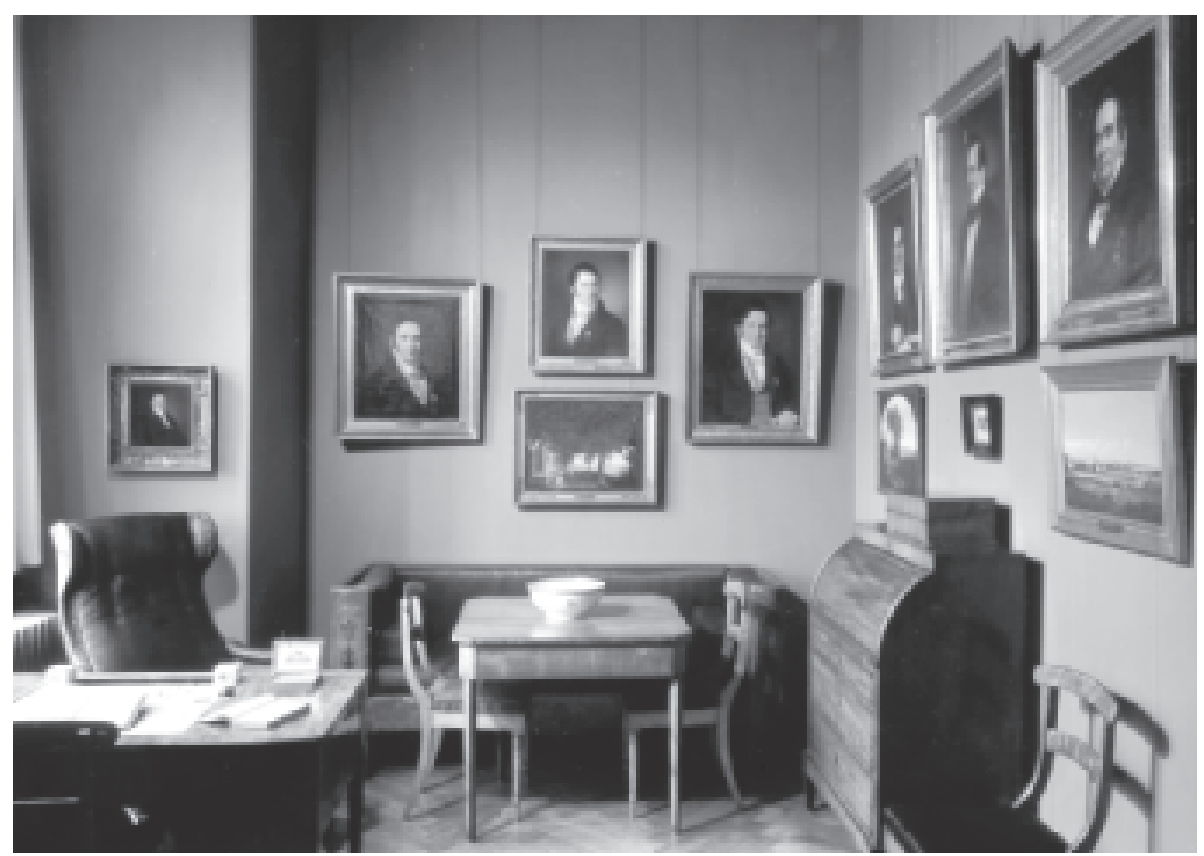

Samme stue fotograferet inden nedtagning i 1999. Man bemarker, at antallet af udstillede malerier og genstande er sterkt reduceret og at stuen fremtreder i en starkt forenklet form. Kit Weiss fot. 1999.

aldrig at blive en del af den tilgængelige del af slottet og blev nedtaget få år efter Meldahls død i 1908. Kun den farverige loftsbemaling er endnu tilbage at se (Andrup1928:35, 4445).

Et andet eksempel på et af museets tidlige interiører - som til gengæld stadig kan ses på museet den dag i dag - er mindestuen over digteren Adam Oehlenschläger. Initiativet til denne stue tog museets bestyrelse allerede $\mathrm{i}$ 1879, hvor man henvendte sig til digterens efterkommere med opfordring til at testamentere museet en del af den store digters efterladenskaber: portrætter, møbler, manuskripter osv. I lyset af tidens fremherskende nationalitetsbegreb, der gjorde sproget og historien lige så vel som den folkelige kultur til kernen i den nationale identitet, var det helt naturligt at give en central placering på et nationalhistorisk museum til en digter som Oehlenschläger. At et interiør var i bestyrelsens tanker fra begyndelsen ses af den første henvendelse, idet man udtrykkeligt anmodede såvel om portrætter som møbler og andre genstande fra digterens hjem. At rummet, da det stod færdigt på museet i 1904, kunne vække følelser hos beskueren, viser en beretning bragt i Illustreret Tidende:

efter vandringen gennem slottets pragtfulde og rigtsmykkede sale, hvor øjet næsten trættes af al denne storhed og glans, studser man uvilkårlig ved at se, at en beskeden, prunkløs og hyggelig stue - en digterstue, hyllet i eftermiddagssolens stråler - så smukt finder 
86 plads mellem disse pragtblændende kongesale... Med ærbødighed træder man ind i dette mindernes tempel og hvor bringer ikke synet af laurbærkransen... hvormed Esaias Tegnér 1829 i Lunds Domkirke kronede "nordiska sångarekungen, tronarfvingen i diktningens verld" os i en forunderlig stemning... med hvilke følelser nærmer man sig ikke dernæst digterens skrivebord, der under glasdække rummer så mange talende seværdigheder... hvor glædes man ikke ved synet af hans smukke chatol... det er mange følelser og tanker, denne digterstue kalder frem ved sine stilfærdige og talende relikvier (Illustreret Tidende 1904:529-30).

I virkeligheden udtrykker denne skildring på eksemplarisk vis det samme som Bernhard Olsen oplevede i Paris, da han blev betaget af den frisiske bondestue på Verdensudstilligen, fascinationen ved disse fuldt udstyrede interiører på en udstilling, hvilket på dette tidspunkt var en relativt ny tilgang til mediet.

I tidens løb har gæsterne på Frederiksborg da også til stadighed kunnet glæde sig over den lille digterstue med den store rigdom af minder. Men lidt efter lidt er der sket en vis udtynding af denne overflod. Bevaringsmæssige hensyn, sikring mod tyveri osv. har gjort, at museet gradvis har indskrænket antallet af de udstillede genstande. En sammenligning af fotografier af digterstuen fra betyndelsen af dette århundrede med de sidste optagelser inden den gamle Oehlenschlägerstue blev nedtaget i forbindelse med installation af elevator, illustrerer tydeligt denne udvikling. Mange genstande er fjernet, og med dem måske også en del af den følelse af liv og nærhed, som udmærkede de tidligere udstillinger. Kombineres dette med en gradvis udtynding i de besøgendes paratviden og kendskab til forrige århundreders politiske og kulturelle personligheder og begivenheder, kan der snart opstå formidlings- og forståelsesmæssige problemer.
På den anden side er et interiør som Oehlenschlägerstuen såvel som de øvrige interiører på Frederiksborgmuseet enestående og vanskelige at erstatte med noget andet og bedre. Brygger Jacobsen tilstræbte ikke et dødt personalhistorisk museum, han drømte om let tilgængelige historiske indtryk og stemninger, hvor kunstværker og de stemningsfulde interiører indgik i en helhed. Derfor har museet også ved en nyindretning af digterstuen tilstræbt at bringe så mange genstande som muligt tilbage i interiøret for atter at puste liv i rummet (Skougaard 2000:111-112). At interiører har en grundlæggende fascinationsværdi vil enhver, der blev betaget blot ved at læse om slottets indretning i 1600-årene, kunne forstå. Men opstillingen af interiører i en museumsmæssig sammenhæng er en opgave, der til stadighed fordrer bearbejdelse og videreudvikling, således at denne udstillingsform også fremover som for brygger Jacobsen og Bernhard Olsen kan tjene som den tryllestav, der kan gøre svundne tider levende og vækkende for den besøgende.

\section{Noter}

1. Hovedslottet består af tre fløje: Kongefløjen, Kirkefløjen og Prinsessefløjen

2. Sølv- og guldmor er et stof (silke, bomuld eller linned) som ved appretur har fået et vatret udseende, og som anvendes til kostbare klædninger eller tapeter og lignende.

3. Blandt forbillederne for Jacobsen var Versailles i Frankrig og Gripsholm i Sverige med tilsætning af ideer fra Nordiska Museet. I øvrigt blev Frederiksborg Slots renæssancearkitektur arkitektonisk reference for udformningen af netop Nordiska Museet.

4. Indretningen af interiører i kronologisk arrangerede rum blev gennemført på Rosenborg allerede 
i 1830erne. Da J.J.A. Worsaae blev direktør i 1858, stod han for en udvidelse, hvor der skabtes en række rum, som førte op til Frederik VIIs tid. Worsaae har således tidligt været fortrolig med indretning af interiører. Se i øvrigt Bencard 1984. Tak til Bjarne Stoklund for at have gjort mig opmærksom på dette.

5. Tak til J.R.Brighton for gennemlæsning af engelsk summary

\section{LitTERATUR}

Andrup, Otto (1928) Det Nationalhistoriske Museum paa Frederiksborg 1878-1928. København.

Beckett, Francis (1914) Frederiksborg. II. Slottets Historie. København.

Bencard, Mogens (1984) The Royal Danish Collections at Rosenborg. The International Journal of Museum Management and Curatorship 1984, 3, s. 221-236.

Bligaard, Mette (1987) Frederiksborg Slot. Kongeborg og Museum. Herning.

Bligaard, Mette (1997) J.C. Jacobsen og Frederiksborg. Mette Bligaard, red.: J.C. Jacobsen og Frederiksborg, s. 16-32.

Glamann, Kristof (1997) J.C.Jacobsen. Brygger og Mæcen. Mette Bligaard, red.: J.C.Jacobsen og Frederiksborg, s. 6-15.

Høyen, A. (1831) Frederiksborg Slots Beskrivelse. København.

Illustreret Tidende 1879, 1904.

Mogensen, Margit (1993) Eventyrets Tid. Danmarks deltagelse $i$ Verdensudstillingerne 1851-1900. Odense.

Olden-Jørgensen, Sebastian (1996) Statsceremoniel, hofkultur og politisk magt i overgangen fra adelsvælde til enevælde - 1536 til 1746. Fortid og Nutid 1996, s. 3-20.

Olsen, Bernhard (1895) Sengekamre og Senge. Tidsskrift for Kunstindustri 1895.

Olrik, Jørgen(1903) Borgerlige Hjem i Helsingør for
300 Aar siden. København.

Petersen, A. (1866) Frederiksborg Slots Inventarium af 1650. København.

Rasbech, Johan Peter: Frederiksborg Slots Beskrivelse. København 1932.

Rasmussen, Holger (1979) Bernhard Olsen. Virke og Varker. København.

Schepelern, H.D. (1964) Frederiksborg Museet.

Kunstindustri. Upubliceret manuskript, Frede-

riksborgmuseets manuskriptsamling.

Skougaard, Mette (2000) Oehlenschlägerværelset -

en digterstue på Frederiksborgmuseet. Carlsberg-

fondets Arsskrift 2000, s. 104-113.

Wolf, J.L. (1654) Encomion Regni Dani๔. København.

\section{SuMMARY}

\section{Interiors at Frederiksborg}

Frederiksborg, the royal castle in Hillerød, north of Copenhagen, was built at the beginning of the 17th century by King Christian IV as his most resplendent residence. It was used as a royal residence for over 200 years until fire destroyed most of its interior in 1859 . During the following decades, the castle was rebuilt and the interiors gradually restored. Finally, on the initiative of the founder of the Carlsberg Breweries, J.C. Jacobsen, the castle was converted into a museum of Danish National History in 1878.

Visitors to the museum today, are perhaps unaware that they are passing through rooms dating from vastly different periods of time. In fact, the interior comprises rooms that are of fundamentally different in that they, range from original interiors that survived the fire of 1859 to those that were restored following the fire, and finally to the museum-interiors created gradually from 1878 onwards. Through an examination of these stages of restoration and development, this article attempts to broaden the conceptual framework for the understanding of museum interiors.

The carefully noted descriptions in the royal inventories together with the few rooms that survived the 
88 fire of 1859 make it possible to imagine the true magnificence of the original interiors of the castle. They also provide evidence that the king had a perfect understanding of the symbols of power and authority needed to impress other regents and the nobility. The furniture and other items were made of the most precious materials; walls were covered with tapestries woven with silk, silver and gold, displayed alongside the finest imported paintings. However, we can only imagine and surmise this splendour, as almost all of these treasures were lost in the tragic fire of 1859 .

The second type of interiors in the museum are the rooms that were reconstructed to appear as they would have been at the time of Christian IV. The most impressive of the restorations is that of the great Hall, an undertaking of such enormous proportions that it took 28 years to complete the reproduction of tapestries for the walls.

The final part of our journey through the castle's restoration culminates with the interiors which embrace the ideas of the museum founder, J.C. Jacobsen. A review of the museum's founding statutes reveal that there was a process during which significant changes were made. Originally, in April 1878, Jacobsen viewed the museum as a testament to the period from early Christian times to about 1660 . Accordingly, the museum interiors were to include furniture, arms, costumes etc. that were representative of the period. But an appendix from October 1878 changes the time span and original scope of the museum. The new vision embraced "more comprehensive presentations of national history from the introduction of Christianity in Denmark to the present day“. This fundamental expansion to include modernity can be seen in relation to the planning efforts undertaken at precisely the same time for the great Exhibition of Art and Industry held in Co- penhagen in 1879. The close connection with Frederiksborg is no surprise given the fact that the chairman of the exhibition committee was the archaeologist J.J.A Worsaae, who was also the chairman of the governing body of the Frederiksborg Museum. It can be shown that the connection to the Exhibition of Art and Industry in Copenhagen 1879 was not only at the conceptual level, there are also striking thematic similarities in the way the interiors were arranged, including beautifully furnished rooms in which portraits of important people were placed. In many cases the self- same pieces of furniture and utensils were later displayed at Frederiksborg. This is in large part also credited to the generosity of J.C. Jacobsen, who was a frequent visitor to the Art and Industry exhibition, and who made it financially possible to purchase many of the items included in the museum during this period.

In conclusion one can say that the use of interiors for exhibition purposes is a logical choice in light of the aim of the museum: to create an evocative and comprehensive representation of the nation's history from antiquity to modernity. This concept was in itself a testament to modernity, since the creation of thematic interiors was the most modern form of museum exhibition most modern at the time, well-suited to appeal to all kinds of visitors, the learned as well as the layman, thus making it easy for the visitor to engage in and identify with the nation's history.

\section{Museumsinspektor Mette Skougaard}

Det Nationalhistoriske Museum på Frederiksborg

Adr. DK-3400 Hillerød

Tel. + 45 4826-0439'

Fax. 4824-0966

E-mail: mette.skougaard@frederiksborgmuseet.dk 